\title{
PENERAPAN PENDEKATAN KETERAMPILAN PROSES UNTUK MENINGKATKAN HASIL BELAJAR SISWA PADA MATERI KELILING DAN LUAS LINGKARAN DI KELAS VIII AL BIRUNI SMP ISLAM TERPADU AL FAHMI PALU
}

\author{
Agung Wicaksono \\ Program Studi PGMI, FTIK, Institut Agama Islam Negeri Palu \\ agungwicaksono874@gmail.com
}

\begin{abstract}
ABSTRAK
Tujuan penelitian ini untuk memperoleh deskripsi penerapan pendekatan keterampilan proses dalam upaya meningkatkan hasil belajar siswa pada materi keliling dan luas lingkaran di kelas VIII Al Biruni SMP Islam Terpadu Al Fahmi Palu. Jenis penelitian yang digunakan adalah Penelitian Tindakan Kelas yang mengacu pada model yang dikembangkan oleh Kemmis dan Mc Taggart yang terdiri atas 4 komponen yaitu (1) perencanaan, (2) pelaksanaan tindakan, (3) pengamatan/observasi, dan (4) refleksi. Hasil penelitian menunjukkan bahwa penerapan pendekatan keterampilan proses proses yang memiliki 8 tahapan yaitu (1) pemanasan, (2) pengamatan, (3) interpretasi hasil pengamatan, (4) peramalan, (5) Pengkajian, (6) generalisasi penemuan, (7) penerapan dan (8) komunikasi dengan menggunakan lembar kegiatan siswa dapat meningkatkan hasil belajar siswa pada materi keliling dan luas lingkaran di kelas VIII Al Biruni SMP Islam Terpadu Al Fahmi Palu
\end{abstract}

Kata kunci: Keterampilan Proses, Hasil belajar, Lingkaran.

\begin{abstract}
The purpose of this study was to obtain a description of the application of the process skills approach to improve student learning outcomes at materials circumference and area of circle in class VIII AL Biruni SMP IT Al Fahmi Palu. The design of this research is based on Kemmis dan Mc Taggart Model, it consisted of four components, (1) planning, (2) implementation of the action, (3) observation, and (4) reflection. Data collected in this research is in the form of data obtained from interviews, observations of teacher activities and student activities in the cycle I and cycle II, and the results of tests on a cycle I and cycle II. Based on research results, that applying Process Skill Approach which has 8 steps that is (1) heating, (2) observations, (3) interpretation of the observations, (4) forecasting, (5) Assessment, (6) generalizations discovery, (7) application and (8) communication with use worksheet at materials circumference and area of circle can to improve the results of student's study class VIII AL Biruni SMP IT Al Fahmi Palu
\end{abstract}

Keywords : Process Skill, Study Results, Circle.

\section{PENDAHULUAN}

Peranan matematika sangat besar dalam kehidupan manusia bahkan untuk masa depan suatu bangsa, maka aspek yang perlu diperhatikan adalah pemahaman siswa terhadap konsep matematika, sebab melalui pemahaman konsep, dapat meningkatkan kemampuan berpikir siswa, sehingga akan berdampak terhadap hasil belajar siswa di sekolah. Oleh karena itu, peran guru sangat 
penting sebagai salah satu komponen pembelajaran yang mampu memilih model, metode, strategi ataupun pendekatan yang tepat dengan materi yang akan diajarkan sehingga dapat memberikan pemahaman kepada siswa dan tujuan pembelajaran dapat tercapai.

Salah satu materi yang dipelajari siswa di tingkat SMP/MTs adalah materi geometri. Menurut D. Agustine dan Smith (Sunardi, 2000) bahwa pada dasarnya geometri mempunyai peluang yang lebih besar untuk dipahami siswa dibandingkan dengan cabang matematika yang lain. Hal ini karena ide-ide geometri sudah dikenal oleh siswa sejak sebelum mereka masuk sekolah, misalnya garis, bidang dan ruang. Budiarto (Abdussakir, 2009) menyatakan bahwa tujuan pembelajaran geometri adalah untuk mengembangkan kemampuan berpikir logis, mengembangkan intuisi keruangan, menanamkan pengetahuan untuk menunjang materi yang lain, dan dapat membaca serta menginterpretasikan argumen-argumen matematik.

Namun kenyataanya, fenomena tentang lemahnya pemahaman siswa pada konsep geometri khususnya pada konsep bangun datar masih banyak dijumpai di sekolah, misalnya di Kelas VIII Al Biruni SMP Islam Terpadu Al Fahmi Palu. Berdasarkan hasil wawancara dengan salah satu guru matematika di Kelas VIII Al Biruni SMP Islam Terpadu Al Fahmi Palu pada tanggal 15 November 2018, diperoleh informasi bahwa masih banyak siswa yang mengalami kesulitan pada materi bangun datar, khususnya pada materi keliling dan luas lingkaran. Sebagian besar siswa masih keliru dalam menyelesaikan soal yang berkaitan dengan keliling dan luas lingkaran tersebut, karena mereka cenderung hanya menghafal rumus yang ada, tanpa paham maksudnya. Oleh karena itu, siswa mengalami kesulitan dalam menyelesaikan soal-soal apabila bentuk soal tersebut dimodifikasi dan berbeda dengan contoh soal yang diberikan sebelumnya.

Berikut ini contoh kesalahan siswa yang ditemukan oleh peneliti ketika melakukan tes identifikasi masalah di Kelas VIII Al Biruni SMP Islam Terpadu Al Fahmi Palu pada tanggal 20 November 2019 dalam menyelesaikan soal yang berkaitan dengan keliling dan luas lingkaran.

Soal :

1. Sebuah taman berbentuk lingkaran mempunyai diameter $14 \mathrm{~m}$. Berapakah luas taman tersebut?

2. Sebuah meja berbentuk lingkaran mempunyai diameter $210 \mathrm{~cm}$. Berapa keliling meja tersebut ?

3. Lusi mengukur keliling meja yang berbentuk lingkaran dengan menggunakan tali. Setelah diukur, ternyata panjang tali sama dengan 220 $\mathrm{cm}$. Berapakah luas permukaan meja tersebut?

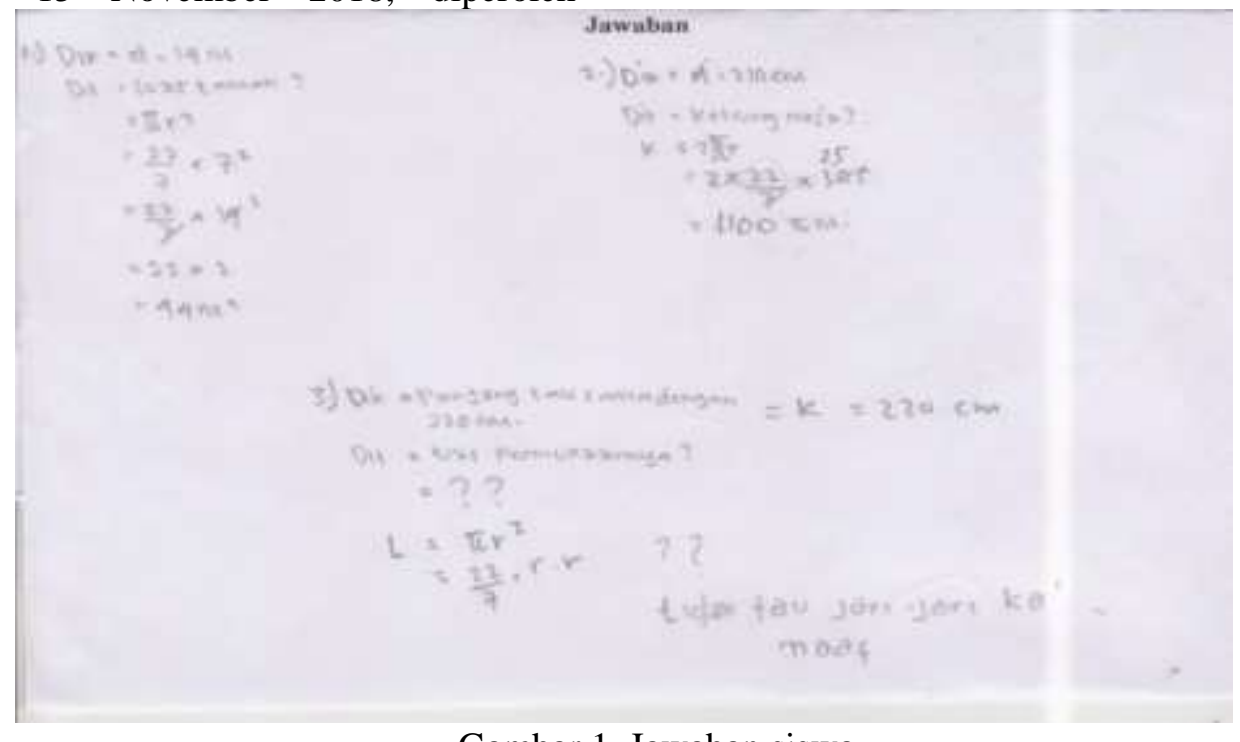

Gambar 1. Jawaban siswa 
Dari data hasil tes di atas (soal no 1), nampak bahwa siswa keliru dalam melakukan operasi aljabar, hal ini mengakibatkan siswa salah dalam menentukan luas taman tersebut. Pada soal no.2, siswa keliru dalam mencari keliling meja tersebut, hal ini disebabkan karena siswa salah, seperti halnya soal no 1 . Akibatnya siswa salah dalam menentukan keliling meja. Pada soal no.3, siswa tidak dapat menyelesaikan soal tersebut dalam mencari luas permukaan meja karena jarijarinya tidak diketahui. Hal ini menunjukkan bahwa siswa kurang terampil dalam menggunakan rumus hubungan antara keliling dan luas lingkaran. Dari 22 siswa yang mengikuti tes tersebut, diperoleh hasil analisis pekerjaan mereka sebagai berikut :

1. Pada soal no.1, tiga orang siswa menuliskan dengan lengkap apa yang diketahui dan yang ditanyakan serta proses penyelesaian soal benar, tetapi keliru dalam menuliskan satuan yang sesuai perintah soal. Dua orang siswa menuliskan dengan lengkap apa yang diketahui serta proses penyelesaian soal benar, namun tidak menuliskan apa yang ditanyakan. Tiga orang siswa salah dalam menggunakan rumus luas lingkaran. Satu orang siswa mengosongkan jawabannya serta sisanya yaitu dua belas orang siswa salah dalam menyelesaikan soal cerita tersebut (seperti jawaban siswa di atas).

2. Pada soal no.2, dua orang siswa menuliskan dengan lengkap apa yang diketahui dan yang ditanyakan serta proses penyelesaian soal benar, tetapi keliru dalam menuliskan satuan yang sesuai perintah soal. Lima orang siswa menuliskan dengan lengkap apa yang diketahui serta proses penyelesaian soal benar, namun tidak menuliskan apa yang ditanyakan. Dua orang siswa salah dalam menggunakan rumus luas lingkaran. Empat orang siswa mengosongkan jawabannya serta sisanya yaitu sembilan orang siswa salah dalam menyelesaikan soal cerita tersebut (seperti jawaban siswa di atas).

3. Pada soal no.3, hanya terdapat satu orang siswa yang menuliskan dengan lengkap apa yang diketahui dan apa yang ditanyakan serta proses penyelesaian benar. Lima orang siswa mengosongkan jawabannya sedangkan sisanya yaitu enam belas orang siswa belum mengetahui cara mencari jari-jari yang kelilingnya diketahui dalam menyelesaikan soal tersebut (seperti jawaban siswa yang di atas).

Kesalahan-kesalahan yang dialami siswa mengakibatkan hasil belajar siswa di sekolah rendah. Calon peneliti berasumsi bahwa permasalahan tersebut disebabkan karena siswa cenderung hanya menghafal rumus yang ada, tanpa ada pemahaman konseptual dan prosedural dalam menyelesaikan masalah, sehingga mengakibatkan belajar dengan cara menghafal tidak menciptakan suatu landasan atau pengetahuan yang dapat dibangun, dan tidak menghasilkan suatu keterampilan atau pengetahuan yang dapat dihubungkan dengan pengetahuan atau keterampilan lain.

Salah satu upaya untuk mengatasi permasalahan tersebut, calon peneliti memilih suatu inovasi pembelajaran yang mengacu pada cara kerja siswa aktif, sehingga diharapkan proses belajar mengajar yang digunakan lebih efektif. Oleh karena itu, calon peneliti mencoba menerapkan suatu inovasi yang dapat mengarahkan siswa sehingga dapat bekerja aktif dalam pembelajaran, yaitu dengan menerapkan pendekatan keterampilan proses.

Teori yang mendukung Pendekatan Keterampilan Proses adalah teori Piaget dan Kontruktivis. Piaget yakin bahwa pengalaman-pengalaman fisik dan manipulasi lingkungan penting bagi terjadinya perubahan perkembangan. Teori perkembangan Piaget memandang bahwa perkembangan kognitif sebagai suatu proses dimana anak secara aktif membangun sistem makna dan pemahaman realitas melalui pengalaman-pengalaman dan interaksiinteraksi mereka. Kontruktivisme menyatakan bahwa pengetahuan akan tersusun atau terbangun di dalam pikiran siswa sendiri ketika siswa berupaya untuk mengorganisasikan pengalaman barunya berdasarkan kerangka kognitif yang sudah ada dalam pikiran siswa.

Menurut Jaeng (2007), pendekatan untuk pembelajaran konsep matematika dapat dilakukan salah satunya dengan cara 
pendekatan keterampilan proses. Salah satu alasan digunakannya pendekatan keterampilan proses ini dalam pembelajaran seperti yang dikemukakan oleh Conny dkk. (Jaeng, 1992) karena tidak mungkin lagi guru mengajarkan seluruh fakta dan konsep kepada siswa karena perkembangan ilmu pengetahuan yang semakin cepat. Selain itu, untuk memudahkan para siswa dalam memahami konsep-konsep yang rumit dan abstrak, mereka perlu mempraktekkan sendiri upaya penemuan konsep melalui pengamatan dan perlakuan. Hal ini sejalan dengan yang dikemukakan oleh Aisyah (2008) yang mengatakan bahwa keunggulan pendekatan keterampilan proses di dalam proses pembelajaran, antara lain adalah (1) siswa terlibat langsung dengan objek nyata sehingga dapat mempermudah pemahaman siswa terhadap materi pelajaran, (2) siswa menemukan sendiri konsep-konsep yang dipelajari, (3) melatih siswa untuk berpikir lebih kritis, (4) melatih siswa untuk bertanya dan terlibat lebih aktif dalam pembelajaran, (5) mendorong siswa untuk menemukan konsep-konsep baru, (6) memberi kesempatan kepada siswa untuk belajar menggunakan metode ilmiah.

Selain itu, Pendekatan Keterampilan Proses juga pernah digunakan oleh Kamaruddin (2008) dan Nurhalidah (2011). Kamarudin meneliti tentang penerapan pendekatan keterampilan proses untuk mengatasi kesalahan prosedur dalam pokok bahasan limit fungsi aljabar siswa kelas XI IPA 4 SMA Negeri 3 Palu. Diperoleh kesimpulan bahwa penerapan pendekatan keterampilan proses terbukti bahwa dapat mengatasi kesalahan prosedur siswa dalam mengerjakan soal pada materi limit fungsi aljabar dan mengetahui secara jelas cara prosedural dalam menyelesaikan soal limit fungsi aljabar. Selanjutnya hasil penelitian yang dilakukan oleh Nurhalida yang meneliti tentang materi bilangan berpangkat dengan menggunakan pendekatan keterampilan proses di kelas XE SMAN 4 Palu menyimpulkan bahwa Pembelajaran matematika pada materi bentuk pangkat dengan menggunakan pendekatan keterampilan proses layak dijadikan sebagai alternatif dalam pembelajaran, karena dapat meningkatkan keterampilan prosedural dalam menyelesaikan soal pada materi bilangan berpangkat sehingga mengakibatkan hasil belajar siswa menjadi lebih meningkat.

Berdasarkan uraian di atas, maka tujuan penelitian ini adalah untuk memperoleh deskripsi penerapan Pendekatan Keterampilan Proses dalam upaya meningkatkan hasil belajar siswa pada materi keliling dan luas lingkaran di kelas VIII Al Biruni SMP Islam Terpadu Al Fahmi Palu.

\section{METODE PENELITIAN}

Jenis penelitian ini adalah penelitian kualitatif dengan pendekatan deskriptif kualitatif. Pendekatan deskriptif kualitatif merupakan pendekatan berupa aktivitas atau perilaku subjek penelitian yang diamati pada saat pembelajaran berlangsung yang datanya diperoleh secara tertulis maupun lisan. Desain penelitian yang digunakan pada penelitian ini mengacu pada model PTK yang dikembangkan oleh Kemmis dan Mc Taggart (Arikunto, 2012) yang terdiri atas 4 komponen yaitu (1) perencanaan, (2) pelaksanaan tindakan,

pengamatan/obesrvasi, dan (4) refleksi. Penelitian ini dilaksanakan di SMP Islam Terpadu AL Fahmi Palu yang berlokasi di jalan gelatik no. 88, Kecamatan Palu Selatan. Subjek penelitian ini adalah seluruh siswa kelas VIII Al Biruni SMP Islam Terpadu Al Fahmi Palu yang terdaftar pada tahun ajaran 2018/2019 yang berjumlah 33 orang. Jenis data dalam penelitian ini yaitu data kualitatif dan data kuantitatif. Data kualitatif berupa aktivitas siswa dan guru selama pembelajaran melalui lembar obdervasi dan wawancara. Sedangkan data kuantitatif digunakan untuk melengkapi data kualitatif berupa hasil pekerjaan siswa dalam menyelesaikan soal baik saat tes awal maupun tes akhir setiap tindakan. Adapun data yang berupa angkaangka dideskripsikan dengan memberi makna dalam bentuk paparan naratif.

Penelitian ini dilaksanakan dalam dua siklus. Setiap siklus dilaksanakan dengan menerapkan pendekatan keterampilan proses Kriteria keberhasilan tindakan pada penelitian ini Siswa mampu melakukan operasi aljabar dalam menentukan keliling dan luas lingkaran setelah mengikuti pembelajaran dengan menggunakan 
pendekatan keterampilan proses. Siswa terampil dalam menggunakan rumus hubungan antara keliling dan luas lingkaran setelah mengikuti pembelajaran dengan menggunakan pendekatan keterampilan proses. Terjadi peningkatan hasil belajar siswa tentang materi keliling dan luas lingkaran setelah mengikuti pembelajaran dengan menggunakan pendekatan keterampilan proses yang terlihat dari perkembangan hasil tes yang diberikan sebelum tindakan dan tes yang diberikan setelah tindakan pada siklus I dan siklus II.

\section{HASIL DAN PEMBAHASAN}

Hasil penelitian terdiri dari dua bagian yaitu (1) hasil pra tindakan, dan (2) hasil pelaksanaan tindakan. Pra tindakan dilakukan pada bulan November, tepatnya pada hari Senin tanggal 15 November 2018. Langkah awal yang peneliti tempuh dalam proses identifikasi dan analisis masalah adalah dengan berdialog langsung dengan guru untuk memperoleh gambaran aktivitas pembelajaran yang telah dilaksanakan. Setelah proses refleksi diri yang dilakukan oleh guru tersebut selesai, maka diperoleh informasi bahwa beberapa masalah pembelajaran yang dirasakan membutuhkan solusi yaitu siswa kurang aktif dalam pembelajaran, siswa masih mengalami kesulitan dalam menyelesaikan soal matematika, dan rendahnya hasil belajar siswa pada pelajaran matematika. Masalahmasalah yang telah didaftar tersebut dirasakan banyak terjadi pada materi lingkaran dan materi bangun ruang. Oleh karena itu, akhirnya peneliti menetapkan materi yang akan diteliti adalah materi lingkaran yang dikhususkan pada materi keliling dan luas lingkaran di Kelas VIII. Selanjutnya peneliti melakukan observasi awal terhadap kondisi pembelajaran matematika di Kelas VIII Al Biruni SMP Islam Terpadu Al Fahmi Palu.

Pada hari Kamis tanggal 17 Januari 2019 peneliti melaksanakan tes awal yang bertujuan untuk mengetahui kemampuan awal siswa pada materi keliling dan luas lingkaran dan nantinya akan digunakan sebagai pedoman penentuan informan. Tes tersebut diikuti oleh 31 orang dari jumlah siswa sebanyak 33 orang, sedangkan 2 orang lainnya tanpa keterangan (alpa). Dari hasil analisis tes awal tersebut peneliti memeriksa bahwa dari 31 orang siswa yang mengikuti tes ini, hanya terdapat 2 orang siswa yang dapat menyelesaikan soal yang diberikan dengan tepat dan benar. Ini berarti bahwa terdapat 29 orang siswa yang belum mampu menyelesaikan soal dengan tepat dan benar. Umumnya siswa belum bisa menentukan perbedaan dari diameter lingkaran dan jarijari lingkaran dan membuat kesimpulan mengenai gambar lingkaran yang mempunyai diameter dan jari-jari lingkaran yang berukuran sama, serta sebagian besar siswa salah dalam menentukan unsur-unsur lingkaran.

Pelaksanaan tindakan yang dilakukan terdiri dari dua siklus dan pelaksanaan dari tindakan pada setiap siklus meliputi (1) perencanaan, (2) pelaksanaan tindakan, (3) observasi dan (4) refleksi. Berikut dijelaskan masing-masing tindakan dari siklus I dan II yakni:

Siklus 1

Pelaksanaan tindakan siklus I ini dilaksanakan pada hari Jum'at tanggal 18 Januari 2019 di Kelas VIII Al Biruni SMP Islam Terpadu Al Fahmi Palu dengan materi keliling lingkaran. Proses pembelajaran pada tindakan ini yaitu dengan menerapkan pendekatan keterampilan proses. Adapun langkah-langkah pada pendekatan keterampilan proses yaitu pemanasan, proses belajar mengajar meliputi pengamatan, interpretasi hasil pengamatan, peramalan, pengkajian, generalisasi penemuan, dan komunikasi.

Peneliti memberikan tes akhir tindakan siklus I, yang mana soal yang diberikan terdiri dari 5 nomor yang dilaksanakan pada hari Selasa tanggal 22 Januari 2019. Pelaksanaan tes akhir tindakan ini hanya diikuti oleh 32 orang siswa, sedangkan 1 orang siswa lainnya Sakit.

Berdasarkan analisis hasil tes akhir siswa yang dilakukan peneliti, diperoleh data hasil belajar siswa pada pembelajaran siklus I sebagai berikut : 
Tabel 1. Hasil Belajar Siswa pada Pembelajaran Siklus I

\begin{tabular}{|c|c|c|}
\hline Nilai & Jumlah Siswa & Keterangan \\
\hline $20-50$ & 10 & $\begin{array}{l}\text { Siswa belum memahami secara lengkap rumus keliling } \\
\text { lingkaran sehingga mengakibatkan kesalahan dalam } \\
\text { menggunakan rumus }\end{array}$ \\
\hline $50-75$ & 18 & $\begin{array}{l}\text { Siswa belum memahami secara mendalam rumus keliling } \\
\text { lingkaran sehingga siswa belum mampu menyelesaikan } \\
\text { beberapa soal yang telah di modifikasi dan masih salah dalam } \\
\text { melalkukan operasi aljabar }\end{array}$ \\
\hline $75-80$ & 4 & $\begin{array}{l}\text { Siswa telah memahami rumus keliling lingkaran tetapi masih } \\
\text { melakukan kekeliruan dalam menyelesaikan operasi aljabar } \\
\text { pada penghitungan keliling lingkaran }\end{array}$ \\
\hline
\end{tabular}

Memperhatikan uraian data hasil belajar pada tabel di atas, diperoleh bahwa ternyata terdapat 10 orang siswa belum memahami secara lengkap rumus keliling lingkaran sehingga mengakibatkan kesalahan dalam menggunakan rumus, 18 orang siswa belum memahami secara mendalam rumus keliling lingkaran sehingga siswa belum mampu menyelesaikan beberapa soal yang tingkat kesulitannya lebih tinggi dan masih salah dalam melakukan operasi aljabar dan 4 orang siswa telah memahami rumus keliling lingkaran tetapi masih melakukan kekeliruan dalam menyelesaikan operasi aljabar pada penghitungan keliling lingkaran. Data hasil belajar ini belum mencapai kriteria keberhasilan yang ditetapkan oleh peneliti. Dengan kata lain bahwa indikator keberhasilan tindakan belum tercapai.

Observasi terhadap aktivitas siswa dalam kelompok dan aktivitas guru dilakukan selama kegiatan pembelajaran berlangsung. Adapun hasil observasi aktivitas siswa yang dilakukan oleh teman sejawat peneliti (Inti Nahdataeni), dan lembar observasi aktivitas guru yang dilakukan oleh guru matematika kelas VIII Al Biruni selama dilaksanakannya proses pembelajaran dipaparkan masingmasing sebagai berikut.

Berdasarkan hasil observasi pengamat terhadap aktivitas siswa diperoleh informasi bahwa pada pembelajaran, sebagian besar siswa sudah mengikuti pembelajaran dengan baik, tetapi masih ada beberapa siswa yang belum secara maksimal mengikuti pembelajaran di dalam kelas seperti : 1) ketika mengingat kembali materi tentang unsur-unsur lingkaran, beberapa siswa belum paham tentang materi tersebut; 2) ketika guru menjelaskan materi, tidak ada siswa yang mengemukakan pertanyaan mengenai apa yang dijelaskan; 3) beberapa siswa tidak aktif mengerjakan LKS dan belum mampu menyimpulkan dugaan sementara berdasarkan kegiatan yang ada di LKS; 4) siswa belum secara maksimal dapat menyelesaikan soal yang berkaitan dengan keliling lingkaran.

Berdasarkan data dan hasil analisis hasil observasi dari pengamat bahwa aktivitas guru selama pembelajaran berada pada kategori sedang, tinggi dan sangat tinggi. Pada umumnya aktivitas guru selama pembelajaran dengan menggunakan pendekatan keterampiilan proses dapat dikategorikan baik, walaupun masih ada beberapa tahapan pada pendekatan keterampilan proses guru dikategorikan sedang oleh observer.

Wawancara dilaksanakan pada hari Rabu tanggal 23 Januari 2019, sehari setelah tes akhir tindakan. Peneliti melakukan wawancara terhadap ketiga informan setelah peneliti memeriksa hasil tes akhir yang diberikan pada hari Jum'at. Peneliti hanya melakukan wawancara terhadap ketiga informan karena tidak memungkinkan untuk mewawancarai seluruh subjek (semua siswa kelas VIII Al Biruni) karena keterbatasannya waktu. Adapun fokus pertanyaan yang diberikan ketika melakukan wawancara terkait dengan materi dan metode pembelajaran yang diterapkan. Dari hasil wawancara diperoleh informasi yang beragam dari ketiga informan. 
Berdasarkan hasil wawancara, diperoleh informasi bahwa pada umumnya siswa masih sulit menyelesaikan soal jika yang diketahui diameter atau jari-jari, mereka bingung dalam menentukan rumus yang mana yang akan digunakan dalam menentukan luas keliling lingkaran. Serta terkendala dalam penurunan rumus jika diketahui luas lingkaran dan yang ditanyakan jari-jari lingkaran. Sedangkan mengenai metode pembelajaran yang digunakan, diperoleh jawaban dari informan yaitu sebagai berikut: (1) Seluruh informan senang dengan pembelajaran yang menggunakan pendekatan keterampilan proses, karena pembelajarannya berstruktur dari awal pembelajaran hingga akhir pembelajaran yang dilengkapi dengan pengamatan dan menggunakan alat peraga dalam menemukan rumus keliling lingkaran. Selain itu pembelajaran dengan menggunakan pendekatan keterampilan proses dianggap pembelajaran yang baik karena siswa dilibatkan dalam menemukan rumus tidak seperti pembelajaran sebelumnya yang cenderung menulis dan mendengarkan. (2) Ketiga informan sangat senang belajar yang diawali dengan pengamatan karena mereka dapat benar-benar paham bagaimana menemukan rumus keliling lingkaran serta cara mengaplikasikannya ke dalam soal.

Berdasarkan hasil catatan lapangan, beberapa hal yang menghambat proses belajar mengajar yaitu: (1) Pada saat proses belajar mengajar sudah berlangsung selama 15 menit, ada tiga orang siswa yang baru masuk ke kelas karena datang terlambat ke sekolah. (2) Pada saat pengerjaan Lembar Kegiatan Siswa, suasana sempat gaduh karena terdapat beberapa siswa kesana kemari untuk meminjam alat dan bahan yang digunakan dalam LKS dengan teman mereka. (3) Beberapa siswa kurang aktif dalam mengerjakan Lembar Kegiatan Siswa.
Kegiatan refleksi dilakukan melalui diskusi oleh peneliti bersama dengan observer untuk mengetahui apakah pelaksanaan tindakan pada siklus I dipandang berhasil atau tidak dengan mengacu kepada pencapaian kriteria keberhasilan tindakan yang telah ditentukan sebelumnya. Dari hasil diskusi diperoleh beberapa hal yang perlu diperbaiki pada siklus II antara lain seluruh siswa harus lebih aktif bekerja di LKS dan memberikan perhatian yang lebih pada saat diskusi, guru (peneliti) perlu memberi motivasi yang lebih serta menekankan pada latihan mengerjakan soal, agar mencapai hasil yang maksimal, guru (peneliti) hendaknya mampu memanagemen waktu sehingga pembelajaran dapat berlangsung dengan baik dan tidak terkesan terburu-buru dalam pembelajaran. Selain itu, dari hasil tes akhir tindakan siklus I menunjukkan bahwa hasil tersebut belum memenuhi target pencapaian keberhasilan tindakan. Oleh karena itu, perlu dilaksanakan siklus II dengan berusaha memperbaiki segala kekurangan yang ada.

Siklus 2

Pelaksanaan tindakan siklus II ini dilaksanakan pada hari Jum'at tanggal 25 Januari 2019 dengan materi luas lingkaran. Proses pembelajaran pada tindakan ini yaitu dengan menerapkan pendekatan keterampilan proses meliputi Pengamatan, interpretasi hasil pengamatan, peramalan, pengkajian, generalisasi penemuan, dan komunikasi.

Peneliti memberikan tes akhir tindakan siklus II, yang dilaksanakan pada hari Selasa tanggal 29 Januari 2019,). Pelaksanaan tes akhir tindakan ini diikuti oleh 33 orang siswa. Berdasarkan analisis hasil tes akhir siswa yang dilakukan peneliti, diperoleh data hasil belajar siswa pada pembelajaran siklus II sebagai berikut :

Tabel 2. Hasil Belajar Siswa pada Pembelajaran Siklus II

\begin{tabular}{ccl}
\hline Nilai & Jumlah Siswa & \multicolumn{1}{c}{ Keterangan } \\
\hline $31-50$ & 5 & $\begin{array}{l}\text { Siswa belum memahami secara lengkap rumus luas lingkaran } \\
\text { sehingga mengakibatkan kesalahan dalam menggunakan } \\
\text { rumus } \\
\text { 50-75 }\end{array} 21 \quad \begin{array}{l}\text { Siswa belum memahami secara mendalam rumus luas } \\
\text { lingkaran sehingga siswa belum mampu menyelesaikan }\end{array}$
\end{tabular}




\begin{tabular}{lll}
\hline & & $\begin{array}{l}\text { beberapa soal yang telah di modifikasi dan masih salah dalam } \\
\text { melalkukan operasi aljabar }\end{array}$ \\
$75-95$ & 7 & $\begin{array}{l}\text { Siswa telah memahami rumus luas lingkaran tetapi masih } \\
\text { melakukan kekeliruan dalam menyelesaikan operasi aljabar } \\
\text { pada penghitungan luas lingkaran }\end{array}$ \\
\hline Jumlah & 33 & \\
\hline
\end{tabular}

Memperhatikan uraian data hasil belajar pada tabel di atas, diperoleh bahwa ternyata terdapat 10 orang siswa belum memahami secara lengkap rumus luas lingkaran sehingga mengakibatkan kesalahan dalam menggunakan rumus, 20 orang siswa belum memahami secara mendalam rumus luas lingkaran sehingga siswa belum mampu menyelesaikan beberapa soal yang tingkat kesulitannya lebih tinggi dan masih salah dalam melakukan operasi aljabar dan 3 orang Siswa telah memahami rumus keliling lingkaran tetapi masih melakukan kekeliruan dalam menyelesaikan operasi aljabar pada penghitungan luas lingkaran. Data hasil belajar ini belum mencapai kriteria keberhasilan yang ditetapkan oleh peneliti. Dengan kata lain bahwa indikator keberhasilan tindakan belum tercapai.

Observasi terhadap aktivitas siswa dalam kelompok dan aktivitas guru dilakukan selama kegiatan pembelajaran berlangsung. Adapun hasil observasi aktivitas siswa yang dilakukan oleh teman sejawat peneliti yaitu Inti Nahdataeni, dan lembar observasi aktivitas guru yang dilakukan oleh guru matematika kelas VIII Al Biruni SMP Islam Terpadu Al Fahmi Palu selama dilaksanakannya proses pembelajaran. Berdasarkan hasil observasi pengamat terhadap aktivitas siswa diperoleh informasi bahwa pada pembelajaran, sebagian besar siswa sudah mengikuti pembelajaran dengan baik, tetapi masih ada beberapa siswa yang belum secara maksimal mengikuti pembelajran didalam kelas seperti : 1) ketika guru menjelaskan materi, hanya sebagian siswa yang mengemukakan pertanyaan mengenai apa yang dijelaskan; 2) beberapa siswa bingung ketika mengerjakan LKS; 3) beberapa siswa belum secara maksimal dapat menyelesaikan soal yang berkaitan dengan keliling lingkaran. Berdasarkan data dan hasil analisis hasil observasi dari pengamat selama kegiatan pembelajaran pada siklus II ini berlangsung, menunjukkan bahwa guru (peneliti) telah melaksanakan prosedur pembelajaran sesuai dengan Rencana Pelaksanaan Pembelajaran yang telah disusun. Pada umumnya aktivitas guru (peneliti) selama pembelajaran dengan menggunakan pendekatan keterampilan proses dapat dikategorikan tinggi dalam melaksanakan prosedur pembelajaran.

Wawancara dilaksanakan pada hari Kamis tanggal 31 Januari 2019, dua hari setelah tes akhir tindakan. Peneliti melakukan wawancara terhadap ketiga informan setelah peneliti memeriksa hasil tes akhir yang diberikan pada hari selasa. Peneliti hanya melakukan wawancara terhadap ketiga informan karena tidak memungkinkan untuk mewawancarai seluruh subjek (semua siswa kelas VIII Al Biruni) karena keterbatasannya waktu., sedangkan hasil pekerjaan informan yang diwawancarai beserta transkip wawancara. Adapun fokus pertanyaan yang diberikan ketika melakukan wawancara terkait dengan materi dan metode pembelajaran yang diterapkan. Dari hasil wawancara diperoleh informasi yang beragam dari ketiga informan.

Berdasarkan hasil wawancara, diperoleh informasi bahwa pada umumnya siswa masih sulit menyelesaikan soal, mereka bingung dalam menentukan rumus yang mana yang akan digunakan dalam menentukan luas lingkaran sehingga mereka terkadang menggunakan rumus keliling lingkaran. Serta terkendala dalam penurunan rumus jika diketahui keliling lingkaran dan yang ditanyakan luas lingkaran. Sedangkan mengenai metode pembelajaran yang digunakan, diperoleh jawaban dari informan yaitu sebagai berikut: (1) Seluruh informan senang dengan pembelajaran yang menggunakan pendekatan keterampilan proses, karena pembelajarannya berstruktur dari awal pembelajaran hingga akhir 
pembelajaran yang dilengkapi dengan pengamatan dan menggunakan alat peraga dalam menemukan rumus keliling lingkaran. Selain itu pembelajaran dengan menggunakan pendekatan keterampilan proses dianggap pembelajaran yang baik karena siswa dilibatkan dalam menemukan rumus tidak seperti pembelajarn sebelumnya yang cenderung menulis dan mendengarkan. (2) Ketiga informan sangat senang belajar yang diawali dengan pengamatan karena mereka dapat benar-benar paham bagaimana menemukan rumus luas lingkaran serta cara mengaplikasikannya ke dalam soal.

Berdasarkan hasil catatan lapangan beberapa hal yang menghambat proses belajar mengajar yaitu: (1) Pada saat peneliti hendak masuk ke kelas, di ruangan kelas hanya terdapat 15 orang siswa, diakibatkan karena cuaca mendung sehingga siswa lain datang terlambat. Konsekuensinya, peneliti harus menunggu siswa lain yang datang terlambat tersebut selama 15 menit.(2) Suasana kelas sangat riuh karena siswa terlalu bersemangat bekerja di LKS.

Kegiatan refleksi dilakukan melalui diskusi oleh peneliti bersama dengan observer untuk mengetahui apakah pelaksanaan tindakan pada siklus II dipandang berhasil atau tidak dengan mengacu kepada pencapaian indikator keberhasilan tindakan yang telah ditentukan sebelumnya. Dari hasil diskusi diperoleh bahwa aktivitas siswa selama kegiatan pembelajaran mengalami peningkatan, baik dalam mengerjakan LKS, bertanya, mengeluarkan pendapat maupun pada saat mengerjakan LKS yang mana dapat disimpulkan bahwa kemampuan siswa dalam memahami dan menyelesaikan masalah meningkat pada siklus II ini. Demikian pula pada hasil belajar siswa, yang mana pada siklus II terjadi peningkatan hasil belajar dari siklus I, walaupun peningkatan hasil belajar tidak signifikan.

Dengan demikian dapat disimpulkan bahwa kriteria keberhasilan tindakan belum telah tercapai. Walaupun secara hasil nilai mengalami peningkatan tetapi ada dua kriteria keberhasilan tindakan belum tercapai yaitu sebagian siswa belum mampu melakukan operasi aljabar dalam menentukan keliling dan luas lingkaran serta belum terampil dalam menggunakan rumus hubungan antara keliling dan luas lingkaran setelah mengikuti pembelajaran dengan menggunakan pendekatan keterampilan proses.

\section{Pembahasan}

Adapun pendekatan keterampilan proses yang diterapkan dalam penelitian ini terdiri 8 langkah yaitu Pengamatan, interpretasi hasil pengamatan, peramalan, pengkajian, generalisasi penemuan, dan komunikasi.

Tahap Pemanasan dimulai dengan membuka kegiatan pembelajaran diantaranya dengan memberi salam, membaca doa, mengabsen siswa, menyampaikan tujuan pembelajaran serta memberikan gambaran tentang proses pembelajaran yang akan berlangsung nantinya. Kegiatan selanjutnya adalah pemberian motivasi oleh peneliti kepada seluruh siswa. Peneliti menekankan bahwa materi yang akan dipelajari sangatlah penting bagi siswa baik untuk pelajaran matematika yang lebih kompleks nantinya maupun bagi kehidupan siswa sehari-hari. Kegiatan dilanjutkan dengan mengingatkan materi sebelumnya yang telah diberikan. Kemudian peneliti mengorganisir siswa untuk mempersiapkan alat-alat peraga yang digunakan dalam pembelajaran

Pada tahap pengamatan, penyajian materi dilakukan dengan ceramah, tanya jawab dan pengamatan. Peneliti mengawali dengan memberikan contoh keliling dari sebuah lingkaran dengan menggunakan alat peraga yang diikuti oleh para siswa. Selanjutnya, peneliti memberikan kesempatan kepada siswa untuk menjelaskan apa yang diperolehnya kemudian bersamasama dengan peneliti menyimpulkan definisi dari keliling dan luas lingkaran. Kemudian dengan alat peraga yang ada, siswa di bantu oleh peneliti untuk menemukan rumus keliling dan luas lingkaran.

Pada tahap Interpretasi hasil pengamatan guru membagikan Lembar Kerja Siswa yang menggunakan pendekatan keterampilan proses untuk dikerjakan dengan teman sebangkunya dan selanjutnya siswa di bantu oleh peneliti untuk menemukan rumus keliling dan luas lingkaran dengan menggunakan alat peraga yang telah disiapkan hingga menemukan rumus untuk 
mencari rumus keliling dan luas lingkaran. Selanjutnya guru menginterpretasikan pemahaman sementara berdasarkan data yang terkumpul dan informasi awal yang berada di LKS kemudian menghubungkannya dengan kenyataan yang berada dilingkungan siswa serta memberikan penjelasan mengenai kegiatan yang siswa lakukan di dalam mengerjakan LKS.

Pada tahap Peramalan peneliti membimbing siswa untuk meramalkan atau menyimpulkan kemungkinan yang akan terjadi dari kegiatan menafsirkan yang telah di lakukan berdasarkan LKS. Beberapa siswa masih menemui kesulitan dalam meramalkan setiap tahapan yang berada di LKS.

Pada tahap pengkajian, peneliti membimbing siswa untuk mengkaji setiap kegiatan yang berada di LKS secara mendetail dan terstruktur. Peneliti juga membimbing siswa menganalisis tahap demi tahap yang berada di LKS. Beberapa siswa masih mengalami kesulitan dalam mengkaji tahapan-tahapan di LKS Pada tahap ini peneliti bekerja ekstra kepada siswa agar tidak ada lagi kekeliruan yang terjadi dalam melakukan setiap tahapan di LKS.

Pada tahap Generalisasi Penemuan peneliti membimbing siswa untuk berdiskusi tentang hasil kegiatan yang mereka lakukan dan menyimpulkan hasil kegiatan LKS tersebut meliputi definisi keliling dan luas lingkaran, rumus keliling dan luas lingkaran serta bagaimana cara menyelesaikan soalsoal yang berkaitan dengan keliling dan luas lingkaran.

Pada tahap ini peneliti juga menjelaskan kembali tentang definisi keliling dan luas lingkaran, rumus keliling dan luas lingkaran serta bagaimana cara menyelesaikan soal-soal yang berkaitan dengan keliling dan luas lingkaran. Selanjutnya peneliti juga memberikan berbagai macam bentuk soal yang berhubungan dengan keliling dan luas lingkaran.

Pada tahap Penerapan peneliti membimbing siswa untuk menerapkan hasilhasil yang telah diperoleh di kegiatan LKS dalam situasi baru yaitu latihan soal. Latihan soal yang diberikan kepada siswa dibuat dengan berbagai bentuk soal tentang keliling dan lingkaran. Selama siswa mengerjalakn latihan soal, peneliti membimbing agar siswa tidak mengalami kesalahan konsep dalam memahami soal.

Setelah menyelesaikan pembelajaran pada kegiatan inti, peneliti melanjutkan pembelajaran pada tahap akhir yakni komunikasi. Adapun kegiatan yang dilakukan adalah meminta siswa membuat kesimpulan dari materi yang telah dipelajari. Peneliti juga memberikan pekerjaan rumah (PR) dengan tujuan untuk melatih kemampuan siswa dalam menyelesaikan soal keliling dan luas lingkaran. Sebelum menutup kegiatan pembelajaran, peneliti menginformasikan kepada siswa bahwa pada pertemuan selanjutnya, akan diadakan ujian tes akhir dan menghimbau agar siswanya belajar dengan baik sebelum ujian. Pembelajaran ditutup dengan membaca doa dan salam.

Berdasarkan hasil penelitian yang telah dikemukakan di atas, diperoleh data dari hasil analisis yaitu untuk tes awal, dari 31 orang siswa yang mengikuti tes, hanya terdapat 2 orang siswa yang memahami secara jelas unsur-unsur dari lingkaran ini berarti bahwa terdapat 29 orang siswa yang yang belum memahami secara jelas unsurunsur dari lingkaran terutama perbedaan jarijari dan diameter pada lingkaran Hal ini menunjukkan bahwa hasil tes awal siswa tentang unsur-unsur lingkaran masih rendah. Rendahnya hasil tes tersebut disebabkan oleh beberapa faktor, diantaranya seperti siswa tidak belajar terlebih dahulu sebelum mengikuti tes, siswa lupa akan materi unsurunsur lingkaran ini, siswa tidak paham dengan materi tersebut dan lain-lain.

Untuk tes akhir tindakan siklus I, diperoleh bahwa ternyata jumlah siswa yang yang mampu menyelesaikan soal berkaitan dengan keliling lingkaran adalah adalah 17 orang siswa dari 31 siswa yang mengikuti ujian, siswa yang mampu menyelesaikan soal keliling lingkaran yang telah dimodifikasi yaitu 10 orang siswa. Hasil tes akhir siklus I ini menunjukkan adanya peningkatan jika dibandingkan dengan hasil tes awal. Walaupun demikian, hasil tes akhir siklus 1 ini belum mencapai kriteria keberhasilan tindakan yang ditetapkan oleh peneliti. Ini berarti bahwa hasil belajar siswa pada soal 
keliling lingkaran masih belum mencapai kriteria keberhasilan tindakan.

Pada pelaksanaan siklus II, pembelajaran berjalan lebih baik lagi dan hasil belajar siswa mengalami peningkatan. Hal ini dapat dilihat dari hasil analisis tes akhir tindakan, diperoleh bahwa dari 33 orang siswa yang mengikuti tes, ternyata 21 siswa mampu mengerjakan soal tentang luas lingkaran tetapi pada soal yang berkaitan dengan hubungan antara keliling dan luas lingkaran hanya 3 orang siswa yang telah mampu menyelesaikannya sedangkan 30 orang siswa lainnya belum mampu menyelesaikan soal tersebut. Ini berarti bahwa indikator keberhasilan tindakan telah belum tercapai sepenuhnya, walaupun terjadi peningkatan hasil belajar tetapi ada beberapa kriteria keberhasilan yang belum dicapai oleh peserta didik.

Dari hasil tes akhir tindakan siklus II tersebut menunjukkan bahwa kemampuan siswa dalam menyelesaikan soal luas lingkaran lebih baik dan meningkat jika dibandingkan pada siklus I mengenai keliling lingkaran. Peningkatan ini disebabkan karena dalam pelaksanaannya, peneliti mengorganisasikan siswa untuk menemukan rumus keliling dan luas lingkaran sesuai dengan tahap-tahap penedekatan keterampilan proses di LKS dan siswa termotivasi untuk mengembangkan pemahamannya dalam mengerjakan LKS yang diberikan dengan baik. Selain itu juga, peningkatan tersebut tak lepas dari pemberian motivasi oleh peneliti, yang mana pada pelaksanaan siklus II ini peneliti memberi penguatan positif kepada siswa berupa pujian dan penghargaan berupa tambahan nilai kepada siswa-siswa yang aktif atau mampu dalam menyelesaikan LKS yang diberikan, menyelesaikan LKS sesuai dengan waktu yang ditetapkan serta mampu mempertanggungjawabkan hasil yang telah diperolehnya sehingga memahami benar apa yang diperolehnya dari LKS. Sehingga semua siswa secara keseluruhan aktif, karena mereka berlomba-lomba untuk mendapatkan penghargaan tersebut. Yang mempengaruhi prestasi belajar atau hasil belajar siswa terdiri dari dua faktor yaitu faktor luar dan faktor dalam. Faktor luar mencakup lingkungan, sedangkan faktor dalam mencakup psikologi yang salah satunya adalah pemberian motivasi.

Pencapaian pada siklus II yang lebih baik dari siklus I tersebut sejalan dengan laporan dari observer yang menyatakan bahwa pembelajaran pada siklus II lebih baik dari siklus I. Hal ini dapat dilihat dari keaktifan siswa selama pembelajaran, yang mana hampir seluruh siswa sudah lebih aktif dalam mengikuti pembelajaran, mereka aktif bertanya, mengajukan pendapat, memaparkan hasil pekerjaannya, dan juga aktif dalam mengerjakan LKS yang telah diberikan. Selain itu juga dapat dilihat dari peningkatan aktivitas guru, terutama pada kemampuan guru untuk mengelola waktu dan membimbing siswa menjadi lebih baik.

Berdasarkan analisis hasil belajar siklus I dan siklus II yang telah dikemukakan di atas, maka dapat disimpulkan bahwa penerapan pendekatan keteramplan proses dapat meningkatkan hasil belajar siswa khususnya dalam menyelesaikan soal tentang keliling dan luas lingkaran di kelas VIII Al Biruni SMP Islam Terpadu Al Fahmi Palu. Walaupun pendekatan keterampilan proses dapat meningkatkan hasil belajar siswa, tetapi beberapa kriteria keberhasilan tindakan belum dicapai oleh siswa.

\section{KESIMPULAN}

Berdasarkan hasil penelitian dan pembahasan, dapat disimpulkan bahwa penerapan pendekatan keterampilan proses yang terdiri dari 8 tahap dapat meningkatkan hasil belajar siswa khususnya dalam menyelesaikan soal tentang keliling dan luas lingkaran di kelas VIII Al Biruni SMP Islam Terpadu Al Fahmi Palu. Walaupun pendekatan keterampilan proses dapat meningkatkan hasil belajar siswa, tetapi beberapa kriteria keberhasilan tindakan belum dicapai oleh siswa.

\section{SARAN}

Pembelajaran pada materi keliling dan luas lingkaran dengan menggunakan pendekatan keterampilan proses yang dilaksanakan dalam bentuk Lembar kegiatan siswa (LKS) layak dipertimbangkan sebagai alternatif pembelajaran di kelas, khususnya untuk melatih keterampilan siswa dalam menemukan rumus keliling dan luas 
lungkaran. Bagi Calon peneliti selanjutnya, yang ingin menggunakan pendekatan keterampilan proses perlu memperhatikan pengaturan waktu dan kelas agar proses pembelajaran dapat berjalan sesuai dengan tujuan pembelajaran yang ingin dicapai.

\section{DAFTAR PUSTAKA}

Abdussakir. (2009). Pembelajaran Geometri dan Teori Van Hiele. (Online), (http://abdussakir.wordpress.com/ 2009/01/25/pembelajarangeometri-dan-teori-van-hiele/), diakses 28 Oktober 2018.

Abidin, Muhammad Zainal (2010). Cara Seseorang Memperoleh Pengetahuan dan Implikasinya pada Pembelajaran Matematika, (Online),

(http://www.masbied.com), diakses tanggal 28 Oktober 2018.

Arikunto, S. (2012). Penelitian Tindakan Kelas. Jakarta: PT. Bumi Aksara

Aisyah, Nyimas. (2008). Pengembangan Pembelajaran Matematika SD. (Online), (http://getskripsi.com/search/penge rtian-pendekatan-keterampilanproses-pada-pembelajaranmatematika/), diakses tanggal 2 November 2018.

Dahniar, Nani. (2006). Science Project sebagai salah satu alternatif untuk meningkatkan Keterampilan Proses sains SMP. Jurnal Pendidikan, 2(1).

Jaeng, Maxinus. (1992). Keterampilan Proses dalam Pengajaran Matematika. Surabaya: IKIP Surabaya.
Kamarudin H.S. (2008). Penerapan mengatasi Kesalahn Prosedur pada Pokok Bahasan Limit Fungsi Aljabar Siswa Kelas XI IPA 4 SMA Negeri 3 Palu. Skripsi tidak diterbitkan. Palu: FKIP Universitas Tadulako.

Nurhalida. (2011). Penerapan Keterampilan Proses Untuk meningkatkan Hasil Belajar Siswa Kelas X E SMA Negeri 4 Palu Pada Materi Bentuk Pangkat. Skripsi tidak diterbitkan. Palu: FKIP Universitas Tadulako.

Sugiyono. (2009). Metode Penelitian Kuantitaif, Kualitatif dan $R \& D$. Bandung : CV Alfabeta.

Sunardi. (2000). Hubungan antara Usia, Tingkat Berfikir, dan Kemampuan Siswa dalam Geometri. Prosiding Seminar Nasional Matematika. Surabaya : Institut Teknologi Sutabaya. 